DOI 10.26886/2414-634X.7(43)2020.10

UDC: $338 ; 658$

\title{
ANALYTICAL BASIS FOR THE DEVELOPMENT OF ADAPTIVE STRATEGIES FOR THE DEVELOPMENT OF SMALL BUSINESS ENTERPRISES
}

\section{N. Holych, Postgraduate student}

https://orcid.org/0000-0003-0499-6979

e-mail:natakv93@gmail.com

Ternopil Ivan Puluj National Technical University, Ukraine, Ternopil

Given the unstable state of the national economy, unfavorable environmental conditions and unhealthy competition in the markets between business entities, there is a need to form an effective set of

strategically effective measures and solutions to be able to respond quickly to destabilizing effects. The state and features of development of small business enterprises of food industry of Ternopil region are investigated; the analysis of activity of the chosen small enterprises of the Ternopil region on the basis of data of the statistical reporting is carried out; the analytical basis of development of adaptive development strategies on the basis of regression analysis is substantiated and the peculiarities of their formation are determined.

Keywords: adaptation, adaptive strategy, small business, regression analysis, bakery industry, food industry.

Голич Н. В., аспірантка кафредри економіки та фрінансів. Аналітичне підгрунтя розробки адаптивних стратегій розвитку підприємств малого бізнесу / Тернопільський національний технічний університет імені Івана Пулюя, Україна, Тернопіль.

В умовах нестабільного стану національної економіки, несприятливих умов зовнішнього середовища та нездорової 
конкуренції на ринках між суб'єктами бізнесу, виникає необхідність формування ефрективного набору стратегічно дієвих заходів та рішень для можливості швидкого реагування на дестабілізуючі впливи. Досліджено стан та особливості розвитку підприємств малого бізнесу харчової промисловості Тернопільської області; здійснено аналіз діяльності обраних підприємств малого бізнесу Тернопільського регіону на основі даних статистичної звітності; обгрунтовано аналітичне підгрунтя розробки адаптивних стратегій розвитку на засадах проведення регресійного аналізу та визначено особливості їх фрормування.

Ключові слова: адаптація, адаптивна стратегія, малий бізнес, регресійний аналіз, харчова промисловість, хлібопекарська галузь.

Постановка проблеми. Сьогодні все дедалі частіше ключовим стимулятором розвитку ринку господарювання $€$ малий бізнес. Безсумнівно, успіх теперішніх ринкових зрушень в економіці України напряму залежить від ії здатності вміло реалізувати та використати потенціал цього динамічного сектору бізнесу. В умовах глобальних економічних змін ефективність будь-якого суб'єкта господарювання залежить від його готовності та вміння швидко пристосуватися до тих умов, які пропонує ринок та середовище. Грамотно сфрормована адаптивна стратегія розвитку служить готовим набором можливих варіантів для підприємств. Це потенціал, який, з одного боку, дозволяє підприємствам малого бізнесу отримати внутрішнє узгодження (тобто правильна позиція стратегії, структури та управління) для того, щоб конкурентоспроможно позиціонувати себе на ринку та, з іншого боку, це зовнішнє узгодження, щоб успішно зреагувати на виклики оточення.

Аналіз останніх досліджень та публікацій. Найбільш вагомий внесок у дослідження питання малого бізнесу зробили українські 
дослідники 3.С. Варналій, В.Є. Сахаров, Я.В. Белінська, О.В. Довгальова, О.В. Балабенко [1-3], які вважають, що малий бізнес $є$ діяльністю будь-яких малих підприємств та окремих громадян (фрізичних осіб), передусім, з метою одержання прибутку, яка не завжди повинна супроводжуватися ризиком і впровадженням інновацій у процесі власної діяльності.

Сутнісна тематика досліджень стратегій розвитку підприємств малого бізнесу в ході процесу адаптації відзначалася у низці наукових праць. До числа цих авторів можна віднести таких дослідників як Н. Ю. Мариненко, Ю. Л. Степанова, Л. В. Соколова, І. В. Струтинська, М. М. Буднік, Ж. Л. Крисько та ін. [4-10].

Окремі аспекти адаптивних стратегій малого бізнесу, пов'язані 3 фракторами, що надають вплив на фрормування стратегій адаптації, їх спрямованості та змісту, вивчаються в працях О. М. Колодіної, Г. Б. Кошарної, К. Є. Орлової, Л. В. Рожкової та ін. [11-12].

Мета статті - обґрунтувати аналітичне підґрунтя розробки адаптивних стратегій розвитку на засадах проведення регресійного аналізу із виокремленням особливостей їх фрормування в мінливих умовах зовнішнього середовища.

Виклад основного матеріалу дослідження. Економічну кризу та негативні соціально-економічні тенденції в Україні неможливо подолати без спільної праці усіх суб'єктів господарювання, вона повинна бути спрямована на зменшення негативних впливів та на створення випереджаючої системи протидії ризикам і загрозам. Підприємства малого бізнесу як наймобільніша ланка на ринку господарювання виступають у ролі медіаторів виходу країни із кризового становища та несуть у собі потенціал економічних трансформаційних змін. Малому бізнесу постійно доводиться адаптуватись до ринкових змін, отримуючи при цьому нові знання як із зовнішніх, так і з внутрішніх 
джерел, що призводить до зростання вимог щодо фрормування адаптивних стратегій підприємницького потенціалу. По своїй суті, адаптивність закладена ще з самого початку в малому бізнесі. Адже він має набагато більшу гнучкість, ніж інші суб'єкти ринку, може швидко реагувати на зміни в попиті, а також характеризується вмінням «вловити» потреби, які виникають у споживачів.

У ході адаптації підприємства малого бізнесу до нових вимог, потреб й умов ринку необхідно мати сформовану свою адаптивну стратегію, котра б характеризувалася чіткістю, синхронністю, злагодженістю дій, а також потужністю інструментів виконання. Дрібні підприємці застосовуючи адаптивні стратегії розвитку на практиці повинні ясно усвідомлювати ступінь власної готовності до підприємницької діяльності в несталий час.

На основі вивчення тверджень, поглядів, думок вітчизняних і закордонних дослідників даної проблематики визначено власне трактування: адаптивна стратегія - це така свого роду стратегія, яка спрямована на розвиток підприємства у майбутньому в умовах невизначеності ринкового середовища та передбачає лише відправну проєктну дію, а вже вибір наступних залежить від результатів попередніх дій та кінцевий результат залежить від кожної дії зокрема. Основна фрункція адаптивної стратегії розвитку - це постійно утримувати підприємство на рівні безперервного розвитку, адекватно реагуючи на стан і зміни в зовнішньому та внутрішньому середовищі.

У процесі дослідження для аналізу обрано окрему галузь харчової промисловості Тернопільської області, а саме хлібопекарську, яка формує рівень національної та регіональної продовольчої безпеки, визначає вартісні показники продукції та ії якість. Хлібопекарська промисловість $€$ важливою складовою продовольчого комплексу України та виробляє 6,9\% продукції харчової промисловості [13]. 
Для детального аналізу діяльності підприємств малого бізнесу хлібопекарської галузі Тернопільської області вибрано 5 підприємств за певними ознаками (розмір, вид економічної діяльності та приналежність до ОТГ в області) - СМП «Форум», ПП «Флюк», ТзОВ «Микулинецький хлібзавод», ТзОВ «РМФ» та ТзОВ «Герчак».

Ефективне виконання адаптивної стратегії підприємствами малого бізнесу на регіональному рівні визначається інфрормативністю параметрів та індикаторів стану зовнішнього і внутрішнього середовища, методами їх вимірювання, якістю керівних впливів і регуляторів. Тому першочерговим завданням $€$ проведення аналізу зовнішніх та внутрішніх фракторів середовища. Оскільки об'єкти дослідження головним напрямом своєї діяльності визначають виробництво хліба, хлібобулочних та борошняних виробів, то доцільно провести аналіз хлібопекарської галузі Тернопільської області.

У процесі дослідження виявлено, що на діяльність підприємств впливають фрактори, які можна розглядати як зовнішні можливості для цих підприємств, і фактори, які створюють зовнішні загрози, негативний вплив яких необхідно знешкоджувати.

Вплив факторів зовнішнього середовища на діяльність хлібозаводів і мініпекарень $€$ неоднаковим. Зокрема, вплив оподаткування $€$ значним для хлібозаводів та незначним для мініпекарень, оскільки хлібозаводи сплачують усі податки, а мініпекарні - єдиний податок. Можливості для зниження витрат, а, відповідно, й перспективна прибутковість на хлібозаводах $€$ більшими. Співвідношення між попитом і пропозицією залежить від попиту споживачів та пропозиції продукції, яка виготовляється. Проте у мініпекарень $€$ більше можливостей для швидкого нарощування обсягів випуску продукції протягом короткого проміжку часу у порівняні 3 хлібозаводами. Оскільки за такий період мініпекарні можуть 
запропонувати більше продукції відповідно до попиту на неї, а в хлібозаводів такі можливості є обмеженими. Хлібозаводи укладають угоди на постачання сировини у великих обсягах, порівняно 3 мініпекарнями, мають більше можливостей для придбання борошна із державного резерву за пільговими цінами. Рівень виробничих зв'язків із постачальниками вищий на хлібозаводах, $€$ більше можливостей впливати на ціну й якість сировини. На діяльність хлібопекарських підприємств та їхню прибутковість найбільший вплив мають високий рівень конкуренції в галузі та споживачі продукції. Під дією цих фракторів формуються обсяги та структура асортименту продукції як на хлібозаводах, так і на мініпекарнях.

Аналіз хлібопекарської галузі в Тернопільській області демонструє наявність численних слабких сторін підприємств малого бізнесу галузі, які потребують вдосконалення законодавства, оцінки фрінансування галузі, покращення виробничих засобів підприємств та ін. Тому для підвищення ефективності функціонування хлібопекарських підприємств в області необхідно розробляти заходи, які будуть спрямовані на забезпечення випуску продукції, яка б відповідала запитам споживачів і була конкурентоспроможною на ринку. Для цього у процесі формування адаптивної стратегії слід на основі проведеного аналізу зовнішнього середовища, провести аналіз внутрішніх сильних і слабких сторін підприємства. Узагальнений аналіз внутрішнього середовища досліджуваних хлібопекарських підприємств Тернопільської області дозволив виявити сильні та слабкі сторони, притаманні хлібозаводам і мініпекарням. Серед сильних сторін виділяють високу кваліфрікацію персоналу, широкий асортимент продукції, швидка адаптація підприємств до місцевих умов, невеликі транспортні затрати та ін. Слабкими сторонами $є$ нестача грошових засобів для просування продукції, відсутність грамотної стратегії, незначні обсяги виробництва 
продукції в галузі, які не можуть здійснювати серйозний вплив на ринкову ситуацію в країні і т.д. На основі встановлення взаємозв'язків між сильними та слабкими сторонами підприємства й зовнішніми можливостями та загрозами можна розробити та обґрунтувати систему заходів необхідних при формуванні адаптивної стратегії розвитку підприємств.

Адаптивні стратегії розвитку власного пропонування (інноваційна, ринкова, внутрішньоуправлінська, інвестиційна [14]) мають свою систему вимірників ефективності, які характеризують окремий напрям кожної із них. Наприклад, основними вимірниками інноваційної адаптивної стратегії розвитку $є$ фондовіддача, рентабельність продукції, матеріаломісткість; внутрішньоуправлінської - чисельність працюючих, продуктивність праці, показник конфліктності; ринкової рентабельність продажів, коефіцієнт завантаження; інвестиційної коефіцієнт інвестування, прибутковість інвестицій у підприємство та ін. Проте, вимірники кожної із стратегій характеризуються неоднорідністю, адже мають різні одиниці виміру. Внаслідок цього, порівняльний аналіз підприємств малого бізнесу доцільно проводити за допомогою показників, котрі 6 враховували нерівномірності розвитку кожного із підприємств для проведення їх ранжування і рейтингового аналізу.

Для визначення оцінки ефрективності стратегічного управління розвитком досліджуваних підприємств малого бізнесу хлібопекарської галузі використано економіко-математичне моделювання, а саме регресійний аналіз - математичний метод прогнозування, результатом якого є рівняння з однією або більшою кількістю незалежних змінних, що використовується для визначення залежної змінної. У такому випадку можна використати функцію, згідно з якою можна встановити вплив параметрів на залежну змінну - багатофакторну регресію:

$$
A S=a_{0}+a_{1} x_{1}+a_{2} x_{2}+\cdots+a_{n} x_{n}
$$


де AS - результативний показник;

$\mathrm{X}_{1}, \mathrm{X}_{2}, \ldots, \mathrm{X}_{\mathrm{n}}$ - досліджуванні фрактори в межах складової адаптивної стратегії підприємства малого бізнесу;

$a_{0}, a_{1}, \ldots, a_{n}$ - параметри, що характеризують фрактори;

$\mathrm{n}$ - кількість показників.

Зміст регресійного аналізу полягає в дослідженні того, як зміна незалежних змінних впливає на залежну зміну. Будуючи регресійну модель взято до уваги дані статистичної звітності підприємств малого бізнесу хлібопекарської галузі в Тернопільській області за 2014-2018 роки. Статистичні дані для побудови регресійної моделі взаємозв'язку прибутку та витрат на проведення адаптаційних змін наведено у таблиці 1.

За результатами проведення регресійного аналізу зв'язку між сумою чистого прибутку та собівартістю продукції, вартістю основних виробничих засобів, чисельністю працівників та сумою податку на прибуток (поле кореляції, лінія регресії, рівняння регресії та коефіцієнт апроксимації) для всіх досліджуваних підприємств обрано найбільш прийнятний для подальшої інтерпретації зв'язок. Для СМП «Форум», ПП «Флюк», ТзОВ «РМФ» та ТзОВ «Герчак» виділено зв'язок між сумою чистого прибутку та величиною податку з прибутку, оскільки йому відповідає найвище значення коефіцієнта апроксимації регресійного рівняння $R^{2}=0,9899, R^{2}=1, R^{2}=0,9736$ та $R^{2}=1$ відповідно, а для ТзОВ «Микулинецький хлібзавод» - між чистим прибутком та собівартістю продукції $\mathrm{R}^{2}=0,9816$ (рис. 1). 


\section{Статистичні дані для побудови регресійної моделі}

Таблиця 1

за 2014-2018 pp.

\begin{tabular}{|c|c|c|c|c|c|}
\hline \multirow[b]{2}{*}{ Роки } & \multirow[b]{2}{*}{$\begin{array}{c}\text { Чистий } \\
\text { прибуток } \\
\text { Y, } \\
\text { тис. грн. }\end{array}$} & \multicolumn{4}{|c|}{ Фактор впливу } \\
\hline & & $\begin{array}{c}\text { Собівартість } \\
\text { продукції } \\
\text { X1, тис. грн. }\end{array}$ & $\begin{array}{c}\text { Основні } \\
\text { виробничі } \\
\text { засоби } X_{2} \text {, } \\
\text { тис. грн. }\end{array}$ & $\begin{array}{c}\text { Чисельність } \\
\text { працівників } \\
\text { Х3, чол. }\end{array}$ & $\begin{array}{c}\text { Податок } \\
\text { на } \\
\text { прибуток } \\
X_{4}, \\
\text { тис. грн. }\end{array}$ \\
\hline \multicolumn{6}{|c|}{ СМП «Форум» } \\
\hline 2014 & 8 & 830 & 118 & 19 & 2 \\
\hline 2015 & 18,9 & 923,2 & 118 & 18 & 4,2 \\
\hline 2016 & 10,3 & 969,1 & 118 & 15 & 2,3 \\
\hline 2017 & 11,3 & 1074,6 & 125,3 & 12 & 2,5 \\
\hline 2018 & 11,8 & 1239 & 125,3 & 12 & 2,6 \\
\hline \multicolumn{6}{|c|}{ ПП «Флюк» } \\
\hline 2014 & 28,7 & 1645 & 519,4 & 21 & 6,3 \\
\hline 2015 & 104,1 & 2000,7 & 776,9 & 21 & 22,8 \\
\hline 2016 & 102,3 & 2348,1 & 875,2 & 28 & 22,5 \\
\hline 2017 & 38,3 & 2996 & 1262 & 28 & 8,4 \\
\hline 2018 & 217,5 & 3641,3 & 1695,5 & 28 & 47,7 \\
\hline \multicolumn{6}{|c|}{ ТзОВ «Микулинецький хлібзавод» } \\
\hline 2014 & -312 & 4032 & 689 & 38 & - \\
\hline 2015 & -578 & 5886 & 689 & 38 & - \\
\hline 2016 & -60 & 1847,6 & 689 & 2 & - \\
\hline 2017 & 10 & 955 & 689 & 2 & 2,2 \\
\hline 2018 & 4 & 580 & 689 & 2 & 0,88 \\
\hline \multicolumn{6}{|c|}{$T 3 O B$ «PMФ» } \\
\hline 2014 & 123,4 & 2661,1 & 2721,5 & 36 & 60,9 \\
\hline 2015 & 653,1 & 3994,3 & 4016,8 & 36 & 143,4 \\
\hline 2016 & 1043,3 & 6805,9 & 4914,5 & 31 & 229 \\
\hline 2017 & 231,4 & 10379,9 & 6492,7 & 31 & 50,8 \\
\hline 2018 & 635,9 & 10894,8 & 8082,1 & 31 & 139,6 \\
\hline \multicolumn{6}{|c|}{ ТзОВ «Герчак» } \\
\hline 2014 & 56,1 & 871,4 & 494 & 14 & 12,3 \\
\hline 2015 & 62,3 & 878,3 & 524,3 & 14 & 13,7 \\
\hline 2016 & 86 & 1111 & 887 & 14 & 19 \\
\hline 2017 & 192,4 & 2521,9 & 1346,4 & 24 & 42,2 \\
\hline 2018 & 322,4 & 3638,4 & 1509,3 & 36 & 70,8 \\
\hline
\end{tabular}

Джерело: сформовано автором на основі фрінансової звітності досліджуваних підприємств

Для повноти проведення регресійного аналізу необхідно визначити коефріцієнт еластичності, який обчислюється за фрормулою: 


$$
\mathrm{E}=b \frac{\bar{x}}{y}
$$

де b - коефріцієнт регресії;

$\overline{\mathrm{x}}, \overline{\mathrm{y}}$ - середні значення змінних $\mathrm{x}$ та у.

Зазначений коефіцієнт показує на скільки відсотків у середньому змінюється фрактор впливу зі зміною суми чистого прибутку на $1 \%$.
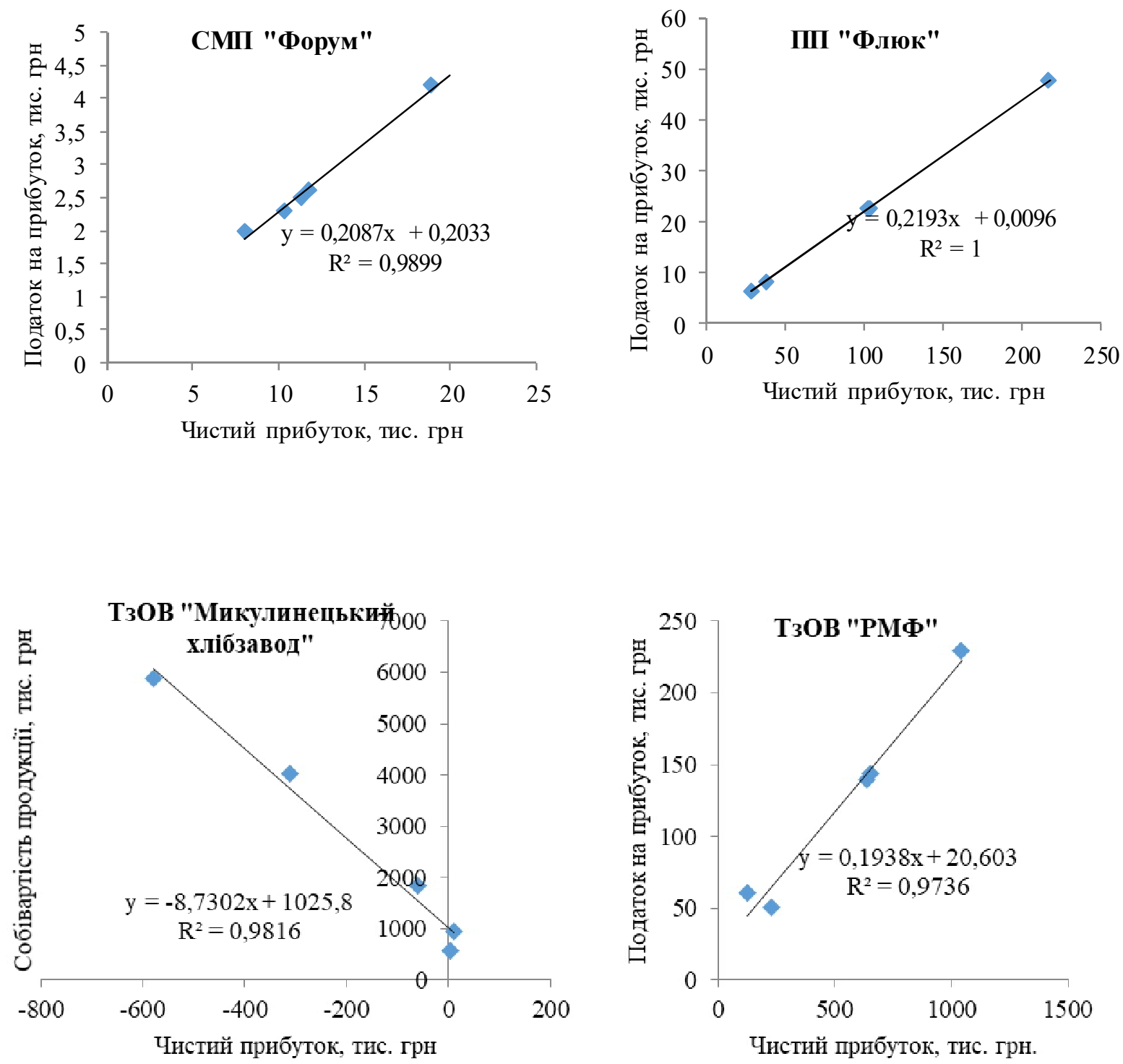


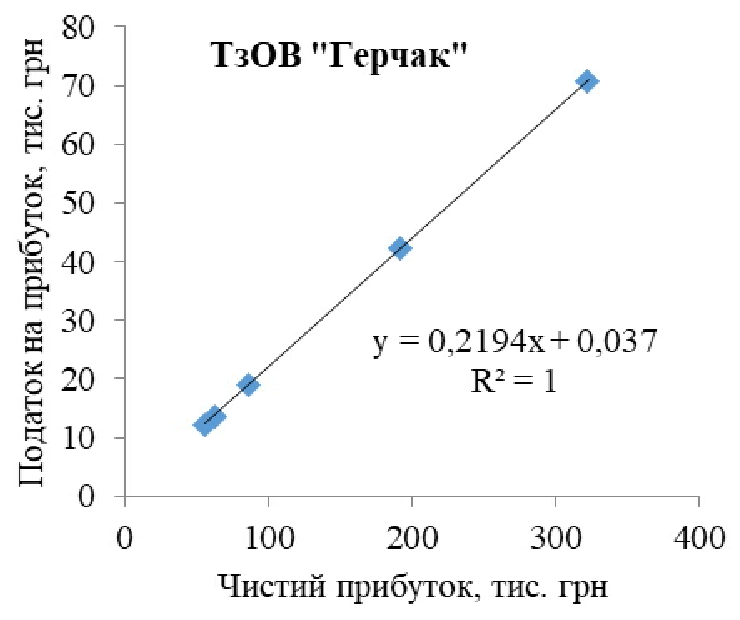

Рис. 1. Результати розрахунку зв'язку суми чистого прибутку із факторами впливу

Джерело: розраховано автором на основі фрінансової звітності досліджуваних підприємств

Таблиця 2

Результати розрахунку регресійної моделі за 2014-2018 рр. для досліджуваних підприємств

\begin{tabular}{|l|l|c|c|c|}
\hline № & \multicolumn{1}{|c|}{ Назва підприємства } & Лінійне рівняння & $\begin{array}{c}\text { Коефіцієнт } \\
\text { апроксимаці } \\
\text { 3/ }\end{array}$ & $\begin{array}{c}\text { Результа } \\
\text { т }\end{array}$ \\
\hline 1. & СМП «Форум» & $\mathrm{y}=0,2087 \mathrm{x}+0,2033$ & $\mathrm{R}^{2}=0,9899$ & 0,47 \\
\hline 2. & ПП «Флюк» & $\mathrm{y}=0,2193 \mathrm{x}+0,0096$ & $\mathrm{R}^{2}=1$ & 0,48 \\
\hline 3. & ТзОВ «РМФ» & $\mathrm{y}=0,1938 \mathrm{x}+20,603$ & $\mathrm{R}^{2}=0,9736$ & 0,44 \\
\hline 4. & ТзОВ «Герчак» & $\mathrm{y}=0,2194 \mathrm{x}+0,037$ & $\mathrm{R}^{2}=1$ & 0,48 \\
\hline 5. & $\begin{array}{l}\text { ТзОВ «Микулинецький } \\
\text { хлібзавод» }\end{array}$ & $\mathrm{y}=-8,7302 \mathrm{x}+$ \\
1025,8 & $\mathrm{R}^{2}=0,9816$ & 6,2 \\
\hline
\end{tabular}

Отже, можна зробити висновок, що настання ризикової події у вигляді зростання відсотка податку з прибутку на 1\% спричинятиме зниження суми чистого прибутку на СМП «Форум»- на 0,47\%, ПП «Флюк» - 0,48\%, ТзОВ «РМФ» - на 0,44\% та ТзОВ «Герчак» - на 0,48\%. Вкрай невтішна ситуація спостерігається на ТзОВ «Микулинецький хлібзавод», котрий протягом аналізованого періоду 
мав збитки в роботі, тому відповідно і прогнозується, що якщо собівартість продукції зросте на 1\%, то чистий прибуток зменшиться аж на $6,2 \%$.

Тепер можна застосувати метод найменших квадратів для кожного підприємства для конкретних зв'язків факторів розвитку.

Регресійний аналіз дав змогу отримати наступні лінійні рівняння:

- для СМП «Форум»:

$$
Y_{t}=-0,8425+4,7435 * X_{1 t}
$$

- для ПП «Флюк»:

$$
Y_{t}=-0,0433+4,5600 * X_{1 t}
$$

- для ТзОВ «РМФ»:

$$
Y_{t}=(-89,3360)+5,0244 * X_{1 t}
$$

- для ТзОВ «Герчак»:

$$
Y_{t}=0,2423+0,0063 * X_{1 t}
$$

- для ТзОВ «Микулинецький хлібзавод»:

$$
Y_{t}=111,8832+(-0,1124) * X_{1 t}
$$

Враховуючи розраховані величини коефіцієнтів кореляції «Множинний R» та детермінації «R-квадрат» розрахунки можна звести

\begin{tabular}{|c|c|c|c|c|}
\hline $\begin{array}{l}\text { № } \\
\text { 3/ח }\end{array}$ & Назва підприємства & $\begin{array}{c}\text { Коефріцієнт } \\
\text { кореляції }\end{array}$ & $\begin{array}{c}\text { Коефріцієнт } \\
\text { детермінації }\end{array}$ & Результат \\
\hline 1 & СМП «Форум» & 0,99 & 0,98 & $\begin{array}{l}\text { Статистично } \\
\text { значуща }\end{array}$ \\
\hline 2 & ПП «Флюк» & 0,99 & 0,99 & $\begin{array}{l}\text { Статистично } \\
\text { значуща }\end{array}$ \\
\hline 3 & ТзОВ «РМФ» & 0,98 & 0,97 & $\begin{array}{l}\text { Статистично } \\
\text { значуща }\end{array}$ \\
\hline 4 & ТзОВ «Герчак» & 0,99 & 0,99 & $\begin{array}{l}\text { Статистично } \\
\text { значуща }\end{array}$ \\
\hline
\end{tabular}
в таблицю 3.

Таблиця 3

Результати розрахунку коефіцієнта кореляції та коефріцієнта детермінації на досліджуваних підприємств 


\begin{tabular}{|l|l|c|c|l|}
\hline 5 & $\begin{array}{l}\text { ТзОВ «Микулинецький } \\
\text { хлібзавод» }\end{array}$ & 0,99 & 0,98 & $\begin{array}{l}\text { Статистично } \\
\text { значуща }\end{array}$ \\
\hline
\end{tabular}

Отже, дана економіко-математична модель $є$ ефективним інструментом прогнозування чистого прибутку від реалізації продукції як одного із показників господарської діяльності підприємства та визначення найвпливовіших факторів на розвиток підприємства. Саме ці результати дозволять підприємствам приймати ефективні рішення в умовах зміни звичної стратегії розвитку на адаптивну, які в кінцевому результаті повинні сприяти отриманню високих прибутків та успіху на ринку.

Висновки та перспективи подальших досліджень. Проведений в ході дослідження регресійний аналіз дає змогу оцінити фрактори впливу на розвиток та фінансово-економічний стан досліджуваних підприємств малого бізнесу та 3-поміж низки аналізованих факторів виявити найбільш значущий для кожного. Відповідно, в процесі роботи виявлено основні загрози для підприємств малого бізнесу хлібопекарської галузі Тернопільської області. Зокрема, це нестійке споживання хліба населенням, зростання споживчих цін на хліб та хлібобулочні вироби швидшими темпами, ніж зростання доходів населення, недосконалість системи контролю якості сировини та продукції на підприємствах, а також відсутність мотивації постачальників борошна та вторинної сировини для виробництва хліба до співпраці призводить до збільшення собівартості продукції та ін.

За теперішніх нестабільних умов зовнішнього середовища, процеси адаптації набувають особливої актуальності 3 точки зору забезпечення стійкості функціонування та розвитку суб'єктів малого бізнесу. Відтак особливої актуальності набуває необхідність визначення механізму та формування адаптивної стратегії розвитку самого підприємства. Чітке досягнення пріоритетів адаптивної стратегії 
забезпечує не тільки стабільне фрункціонування підприємств, а й сприяє руху вперед і виходу на новий якісний рівень свого розвитку.

Діяльність малого бізнесу при виборі адаптивної стратегії визначається можливостями суб'єкта мобілізувати свої внутрішні резерви для забезпечення виживання. В умовах загрози ця здатність посилюється і спонукає систему функціонувати з великим напруженням сил, бути більш «розумною» і креативною, шукати більш правильні рішення, не залишати без уваги ні одну слушну ідею.

\section{תimepamypa:}

1. Варналій, 3.С. (2008). Мале підприємництво: основи теорії $i$ практики (4-те вид.). К.: Т-во «Знання», КОО. 302.

2. Сахаров, В.Є. (Ред.), Белінська, Я.В., Зав'ялова, О.В. та ін. (2003). Малий та середній бізнес. К.: ВН3 «Національна академія управління». 368.

3. Довгальова, О.В., Балабенко, О.В. (2011). Управління малим бізнесом : підручник. Донецьк: Цифрова типографрія. 298.

4. Мариненко, Н.Ю. (2017). Управління адаптивним розвитком виробничо-господарських структур (Автореф. дис. д-ра. екон. наук). Тернопільський національний технічний ун-т, Т. 41.

5. Степанова, Ю.Л. (2010). Класифрікація адаптації підприємства в залежності від прогнозованості виникнення змін у зовнішньому середовищі підприємства. Вісник Східноукраїнського національного університету імені Володимира Даля. 2(2). http://www.nbuv.gov.ua/portal/Soc_Gum/VSUNU/2010_2_2/Stepanova.pdf 6. Соколова, Л.В. (2006). Організаційно-економічне забезпечення адаптації підприємств до невизначеності бізнес-середовища (Автореф. дис. д-ра. екон. наук). НАН України. Ін-т ек-ки пром.-сті. Д. 34. 
7. Соколова, Л. В. (2004). Теорія і практика адаптації підприємств до мінливого бізнес-середовища. Харків : ХНУРЕ. 288.

8. Strutynska, I., Kozbur, H., Dmytrotsa, L., Bodnarchuk, I., Hlado, O. (2019). Small and Medium Business Structures Clustering Method Based on Their Digital Maturity. IEEE International Scientific-Practical Conference Problems of Infocommunications, Science and Technology (PIC S\&T), Kyiv, Ukraine. 278-282.

9. Буднік, М.М. (2002). Адаптація промислових підприємств до ринкових умов господарювання (Автореф. дис. канд. екон. наук). Харківський держ. економічний ун-т. Х. 19.

10. Крисько, Ж.Л. (2009). Адаптація підприємства до змін зовнішнього середовища через механізм реструктуризації. Галицький економічний вісник, 2. 38-42.

11. Колодіна, О.М. (2010). Економічний зміст адаптації підприємства. Вісник Сумського державного університету. Серія Економіка, 1. 200210.

12. Орлова, К.Є. (2013). Організаційно-економічні засади адаптації підприємств добувної промисловості до зовнішнього середовища. Соціально-економічні проблеми і держава, 1(8). 181-189.

13. Ооріційний сайт Державної служби статистики України. http://www.ukrstat.gov.ua/

14. Панухник, О.В., Голич, Н.В. (2020). Використання адаптивного моделювання стратегій розвитку підприємств малого бізнесу в умовах децентралізації. Часопис економічних реформ, 3 (39). 17-28.

\section{References:}

1. Varnalii, Z.S. (2008). Male pidpryjemnytsvo: osnovy teorii i praktyky [Small entrepreneurship: the basics of theory and practice]. Kyiv, T«Znannia», KOU. [in Ukrainian]. 
2. Sakharov, V.le. (Red.), Belinska, Ya.V., Zavialova, O.V. ta in., (2003). Malyi ta serednii biznes [Small and medium business]. K., VNZ «Natsionalna akademiia upravlinnia». [in Ukrainian].

3. Dovhalova, O.V., Balabenko, O.V., (2011). Upravlinnia malym biznesom [Small business management]: pidruchnyk. Donetsk, Tsyfrova typohrafiia. [in Ukrainian].

4. Marynenko N.lu., (2017). Upravlinnia adaptyvnym rozvytkom vyrobnycho-hospodarskykh struktur [Adaptive development management of production and economic organization] (Thesis abstract for Dr. Sc. (Econ.)). Ternopilskyi natsionalnyi tekhnichnyi un-t. T. [in Ukrainian].

5. Stepanova, Yu.L. (2010). Klasyfikatsiia adaptatsii pidpryiemstva v zalezhnosti vid prohnozovanosti vynyknennia zmin u zovnishnomu seredovyshchi pidpryiemstva [Classification of adaptation of the enterprise depending on the predictability of changes in the external environment of the enterprise]. Visnyk Skhidnoukrainskoho natsionalnoho universytetu imeni Volodymyra Dalia [Visnik of the Volodymyr Dahl East Ukrainian National University]. No. 2(2). Retrieved from http://www.nbuv.gov.ua/portal/Soc_Gum/VSUNU/2010_2_2/Stepanova.pdf [in Ukrainian].

6. Sokolova, L.V. (2006). Orhanizatsiino-ekonomichne zabezpechennia adaptatsii pidpryiemstv do nevyznachenosti biznes-seredovyshcha [Organizational and economic support for adaptation of enterprises to uncertainty of the business environment] (Thesis abstract for Dr. Sc. (Econ.)). NAN Ukrainy. In-t ek-ky prom.-sti. D. [in Ukrainian].

7. Sokolova, L.V. (2004). Teoriia i praktyka adaptatsii pidpryiemstv do minlyvoho biznes-seredovyshcha [The theory and practice of adapting enterprises to a changing business environment]. Kharkiv: KhNURE. [in Ukrainian]. 
8. Strutynska, I., Kozbur, H., Dmytrotsa, L., Bodnarchuk, I., Hlado, O. (2019). Small and Medium Business Structures Clustering Method Based on Their Digital Maturity. IEEE International Scientific-Practical Conference Problems of Infocommunications, Science and Technology (PIC S\&T), Kyiv, Ukraine. 278-282. [in English].

9. Budnik M.M., (2002). Adaptatsiia promyslovykh pidpryiemstv do rynkovykh umov hospodariuvannia [Adaptation of industrial enterprises to market conditions of management] (Thesis abstract for Cand. Sc. (Econ.)). Kharkivskyi derzh. ekonomichnyi un-t. Kh. [in Ukrainian].

10. Krysko Zh.L., (2009). Adaptatsiia pidpryiemstva do zmin zovnishnoho seredovyshcha cherez mekhanizm restrukturyzatsii [Adaptation of the enterprise to the external environment through the mechanism of restructuring]. Halytskyi ekonomichnyi visnyk [Galician Economic Bulletin]. No. 2. 38-42. [in Ukrainian].

11. Kolodina O.M., (2010). Ekonomichnyi zmist adaptatsii pidpryiemstva [Economic content of enterprise adaptation]. Visnyk Sumskoho derzhavnoho universytetu. Seriia Ekonomika [Visnyk of Sumy State University. Economy series]. No. 1. 200-210. [in Ukrainian].

12. Orlova K., (2013). Orhanizatsiino-ekonomichni zasady adaptatsii pidpryiemstv dobuvnoi promyslovosti do zovnishnoho seredovyshcha [Organizational-economic basis of extractive industry enterprises adaptation to the external environment]. Sotsialno-ekonomichni problemy $i$ derzhava [Socio-Economic Problems and the State]. Vol. 8, No. 1. 181-189. [in Ukrainian].

13. The Official site of the State Statistics Service of Ukraine. Retrieved from http://ukrstat.gov.ua/ [in Ukrainian].

14. Panukhnyk, O.V., Holych, N.V., (2020). Vykorystannia adaptyvnoho modeliuvannia stratehii rozvytku pidpryiemstv maloho biznesu $v$ umovakh detsentralizatsii [Strategies for development of small business enterprises 
in the conditions of decentralization]. Chasopys ekonomichnykh reform [Time Description of Economic Reforms]. No. 3 (39).17-28. [in Ukrainian].

Citation: N. Holych (2020). ANALYTICAL BASIS FOR THE DEVELOPMENT OF ADAPTIVE STRATEGIES FOR THE DEVELOPMENT OF SMALL BUSINESS ENTERPRISES. New York. TK Meganom LLC. Innovative Solutions in Modern Science. 7(43). doi: 10.26886/2414-634X.7(43)2020.10

Copyright: N. Holych (․) 2020. This is an openaccess article distributed under the terms of the Creative Commons Attribution License (CC BY). The use, distribution or reproduction in other forums is permitted, provided the original author(s) or licensor are credited and that the original publication in this journal is cited, in accordance with accepted academic practice. No use, distribution or reproduction is permitted which does not comply with these terms. 